\title{
保育園児の箱庭制作に見る人間の創作行為の起源 \\ RESEARCH ON HUMAN INVENTIVENESS ORIGINS THROUGH KINDERGARTEN CHILDREN'S SANDPLAY WORKS
}

\author{
坂戸省三*，河内あゆ**，東野 アドリアナ*** \\ Shozo SAKATO, Ayu KAWAUCHI and Adriana HIGASHINO
}

\begin{abstract}
This study utilizes sandplay experiments as a means to analyze the development of 4 and 5 year old kindergarten children's creative spatial organization of toys. The children were asked to arrange several toys in a box filled with sand, and they were told to play in the sand box and with the toys freely. The researchers were able to identify and classify the children's developmental steps in the creation and recognition of their spatial organization of the toys. These steps ranged from the simple displacement of the toys in the box to more complex arrangements where meaningful spatial relationships between the toys were established.
\end{abstract}

Keywords: sandplay works, development of spatial organization, sex differences, archetypical spatial images 箱庭作品，空間構成の発達，男女の違い，原型的空間イメージ

\section{1. はじめに}

本稿は保育園の 4 歳児組および 5 歳児組の園児に箱庭を作っても らい、それを観察することで、園览の箱庭作品にはどのような内容 や形式等が現れるか、また創作行為がどのような要素でできており、 それらがどのように発達していくかを考察したものである。本稿で 考察対象としたのは 4 歳児組（4歳から 5 歳）の男子 10 名、女子 17 名と 5 歳児組（5 歳から 6 歳）の男子 15 名、女子 9 名の箱庭作 品である注 1)。使用した箱庭セットは通常の箱庭療法で用いられて いるもの（砂を入れた $57 \mathrm{~cm} \times 72 \mathrm{~cm} \times 7 \mathrm{~cm}$ 箱と、人、動物、木、花、 乗り物、家具、建築物、橋、椢、兵器、積み木、その他の多様な玩 具類）である。本稿では作品を、発達的視点から、「羅列・混沌」 の段階、玩具が全体的に意味をもって配置された「構造化」の段階、 そして両者の中間的様相の「部分的構造化」の段階などに大きく分 類し、考察を進める。

\section{$1-1$. 箱庭研究の意義}

人間は常に何らかの世界像を現実世界に投げかけ、その結果をフ イードバックさせ、さらに世界像を意識的、無意識的に構築しつつ 存在している。そうした世界像構築作用の早い現れが、幼い子供た ちの積み木遊びやままごとなどの想像的情景を創り出す、玩具世界 での遊びである。幼い子供の玩具世界での遊びは、人間の想像力、 創造的活動の個体発生的起源であり、人間が自分のいる世界を把握

* 明石工業高等専門学校建築学科 教授・博士 (工学)

** 押茶の水女子大学大学院人間文化創成科学研究科ライフサイエンス専攻 大学院生

*** 明石工業高等専門学校建築学科 准教授・博士(工学)
し、経験を整理していく方式の原型をなす。この遊びに関してエリ クソンは「進化に根拠をもち、幼児期の想像力あふれる玩具世界の なかで発達してきた一つの特殊な人間的能力。つまり一つの限定さ れた領域のなかで特殊な象徵的意味を担った物体を用いて想像的情 景を表現する能力 ${ }^{1)} 」$ とうう言い方をしている。箱庭療法はこうし た人間の子供に自然に現れてくる遊びをそのままもちいている。つ まり箱庭制作は人間の世界把握の普遍的方式を反映しているゆえ に、そこには作者がどのように世界を捉えているかがおのずと現れ ているのである。また箱庭療法の道具立ては、臨床上の必要性から、 作者の心にあるイメージが可能な限り自由に表現されるものとして 工夫されてきたことも、こうした傾向をより強めている。

\section{$1-2$ ．これまでの箱庭研究の概要と本稿の位置づけ}

箱庭には作者の個人的な内面を反映したことがらの他、作者が属 する文化圈の特徵、さらには生物学的なヒトとして共通する特徵が 現れる。生物学的基盤に由来する男女の特徴などは基本的でごく当 たり前のものとしてたいていの作品に現れている。

既発表論文 ii （文末既発表論文欄参照）で幼稚園坚から大学生ま での男女約 300 名の箱庭作品（岡田天理資料注 2)）を分析したが、 作者が自由につくるにも関わらず、男女ごと、発達段階ごとに驚く ほど明瞭な共通性が現れている。そしてそれら共通の特徵やテーマ は、各発達段階の男女が一般的に世界・空間をどのように把握して

Prof., Dept. of Architecture, National Institute of Technology, Akashi College, Japan, Dr.Eng.

Grad. Stud., Graduate School of Humanity and Science, Ochanomizu Univ.

Assoc. Prof., Dept. of Architecture, National Institute of Technology, Akashi College, Japan, Dr.Eng. 
いるか、またどのような心理・社会的な空間イメージの中で暮らし ているかを、具体的なかたちをとおして象徵的に表していた。

箱庭に現れる一般的特徴についてまず男子について見ていくと、 移動・侵入的注 ${ }^{3)}$ （幼稚園览の乗り物の多用、小学 3 年の戦いのイ メージにおける戦闘車両、小学 6 年の野生動物原野の動物たち、中 学 2 年の街のイメージでの通過交通、高校生の遍歷的、回遊的イメ ージなど）、外部的（箱の枠を超えて空間的に広がっているイメー ジ）、多元的（いくつかの領域が半ば独立的、半ば連続的に広がっ ているイメージ）といった特徴が多数の作品に現れる。写真 1 は、 郊外の風景のなかを 1 台の車が走っていくという男子高校生の作品 で、移動・侵入的、外部的、多元的な典型的作例である。既発表論 文viii゙こうした形式を「多元性の空間イメージ」と呼ぶことにした。 女子の作品ではどの年齢でも人類共通に「女性的一元性の空間イ メージ」と名づけた形式が大量に現れる（既発表論文ix）。それは、 住人的（人や動物が楽しげに暮らしている様子など）、内部的（箱 庭の枠の中で世界が完結しているイメージ）、内包的（全体あるい は主要な部分が囲われているーただし内包性・囲いが現れない場合 もある）、そして一元的（全体として一つの空間が中心的な位置を しめる）という特徴をもつ。写真 2 は人々や動物たちが楽しげに暮 らしている村のイメージで、その典型例である。なお女性的一元性 の空間と分類した作品には、写真 2 のような全体をその空間が占め るものばかりではなく、女性的一元性の空間と周囲の外部空間とい う構成の作品も多い。その他、20 代前半を中心とした若い女性では 「二つの世界」と呼び慣わされる、川などで全体が二つの領域に分 かれたイメージが世界共通に頻繁に出現する（既発表論文 ii 、ix）。

箱庭にはテーマを超えて上記の形式が現れる。例えば、男子では、 動物原野であろうが、町や郊外の風景であろうが、多元性の空間イ メージの構成をとるものが多く、女子では室内であろうが、庭園や 公園、あるいは村や町であろうが、女性的一元性の空間イメージの 構成をとるものが非常に多い。既発表論文 $\mathrm{v}$ で考察したように、こ れらの基本的な空間イメージは生物学的起源をもつものである。

文化的差異の問題に関しては、多元性の空間イメージは、日本の 建築や庭園に見られる多焦点的、非対称的で水平的に広がった空間 と重なるものであり、一方、ヨーロッパをはじめ大陸の文化圈に属 する男子の箱庭作品（および建築や庭園）には中心化された空間、 中心を通る垂直軸、対称性などの特徴をもつ空間イメージ（「男性 的一元性の空間イメージ」と名づけた）が多く見られる（既発表論 文vi、vii、x）。このイメージは求心的形式と遠心的形式に分ける ことができる (図 1)。多元的なものが中心に集中するイメージ (求 心的形式）と、中心にあるものが多元的なものをまとめ上げ、支配 するイメージ（遠心的形式）である。大陸文化圈の建築によく見ら れるのは遠心的形式であるが、どちらも内に強い攻撃性を秘めたイ メージである。

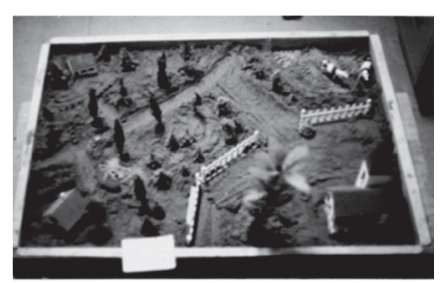

写真 1 多元性の空間 高校生

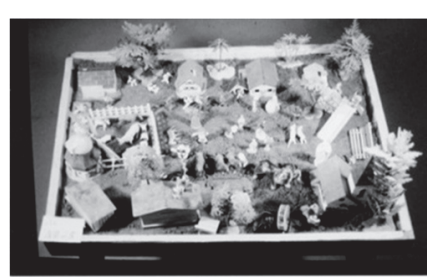

写真 2 女性的一元性 小学 3 年
日本においても、岡田天理資料の小学 3 年生男子群で、写真 3 の ような戦車などによる戦いのイメージとして、中心の一点あるいは 軸線に集中寸る対決的形式の男性的一元性の空間イメージ（求心的 形式）が多量に出現する。日本人男子では、母性的環境から外部世 界に打って出ていく時期である小学 3 年の年齢で、戦いのイメージ として求心的男性的一元性のイメージが多く現れるわけである。そ の他に人生の転換期を迎えるときなど、自ずと無意識裏に攻撃性が 高まっている状態で一時的に現れて来るが、それ以外の日常的な状 態においては多元性のイメージが多数を占める（既発表論文 ii 、iii 、 vi 、vii、viii)。なお攻撃性が男子のようなかたちでは表立っていない 女子においては世界中共通に女性的一元性の空間イメージが多数現 れる（既発表論文ix）。以上のように箱庭作品には一定の空間的形 式をもついくつかの普遍的、基本的な空間イメージが存在する。

今回、園児の箱庭作品では、4 歳児組では羅列的あるいは混沌と した傾向がより強く見られ、一方 5 歳児組では全体的に意味のある 玩具配列の箱庭作品（「構造化」された作品と名づける）が 4 歳児 組より多く見られた。本稿では、箱庭作品に現れる特徵や形式、創 作行為自体の発達的展開を記述していく。また構造化された作品の ほとんどは、男子では上記の「多元性の空間イメージ」、女子では 「女性的一元性の空間イメージ」という形式をとっていることを見 ていくが、それがどのような意味をもつのか等々を考察する。

\section{2. 園児作品の分類}

園児には玩具を使って何かを作るなり、遊ぶなり好きなようにし てもらった。過半は中身が徐々に積み上がっていき、最終的な形が できあがるものだが、一方で次々と場面が変わり変転していくもの があった。またなかには何もせずに帰る者なども少数いた。それで 説明としては「徐々に積み上がり最終的な形ができあがるもの」に 関する分類から始めるのがわかりやすいので、それらから説明する ことにする。表 1 （3ページ後に提示）では園児の箱庭制作におい て顕著に目に付いたことがらを取り上げ、それらが現れた状況を示 す。表の項 $1 \sim 4$ は心理・社会的発達に関するもの、項 $5 \sim 14$ は作 り方などに関するもの、項 15２0 は男女差に関するものである。

\section{$2-1$. 原初的段階}

羅列：玩具相互の関係をほとんど考慮せず、同じようなぺースで 玩具を次々と並べていくもの。4 歳児組男子 1 例 $(10 \%)$ 、同女子 4 例 $(24 \%) 、 5$ 歳児組男子 2 例（13\%）、同女子 3 例（33\%）。

写真 4 は 4 歳児組女子事例 (7) (以下、女 4 (7) と表記。なお同じ箱 庭で制作過程順に写真を複数表示する場合は-1、-2 というように番 号をつける。事例番号は表 1 に示したもの）は雑然と置かれた羅列 の例である。雑然としているが、全く秩序がないわけではなく、玩 具の種類は動物に限定というまとまりがある（カテゴリー的認識）。 写真 5 女 48)では、動物が左下から順に並べられる。この 2 例では

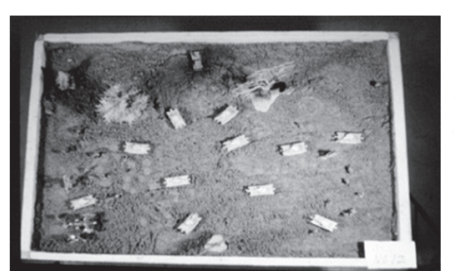

写真 3 男性的一元性 (求心的) 小学 3 年

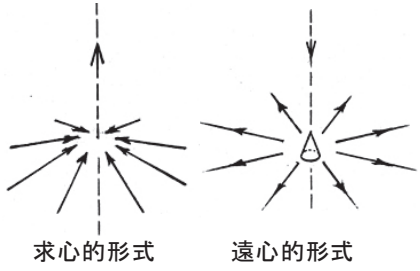

図 1 男性的一元性 
後半動物を砂に埋めたり、砂をかけたりする遊びがなされる。最終 的には前者では多くが砂に埋められ、後者では砂と一緒にかき混ぜ られておしまいになった。両例とも左下から置き始められている。

写真 6 男 4 (5)では、まず空いたところに置いていき、後のほうで は「詰め込むためにすでに置いてあるものを少しずらして」置くと いった操作（表 1 、項 6 、他をずらす）が入っているが、作り始め から終了まで変更もなく置きつづける場合も多い(項 5 、変更なし)。 羅列の配置パターンとしては、写真 4 のように雑然と並べるもの の他、列状に並べるもの（写真 5 ）、正面向き、奥向き、右向きな ど一方向を向いているもの（写真７男５８）、箱の枠と平行に縦横 に置いているもの（写真 6 ）などがある（項 7 に方向を記述）。そ して写真 4、5、7 などの事例で見られたが、左から（特に左下か ら）右上に向けて広がってゆくものが多い（項 10、左から）。左下 から右に向け 1 列目を置き、次にまた左から 2 列目を始めるという 事例もしばしば見られる。写真 8 ～10 女 5 (4)は左下から始まり右上 に向け広がっていく作例の典型である。

また 4 歳児組女子では写真 11 女 4 99ように最初に囲い作った 例が 4 例（24\%）見られた（項 19、囲い）。写真 11 は左上から始 まり時計回りに、消防士、貝、太鼓橋、十字架、家、ジープという ように内容的な意味は見られないしかたで置かれていった。これも 一種の羅列である（女子に見られる囲いについては後述）。なお羅 列段階で現れる諸特徵は、岡崎甚幸らが幼稚園児に対して居住空間 構成法をもちいて行った実験による「構造化された意味のある場を もたない空間構成」の作品群の「正面性保持」、「方向性保持」、 「一様分布」、「列状」、「原初的囲い」といった内容と重なる ${ }^{3)}$ 。

混沌：羅列的に玩具を置く行為が止まらなくなり（項 8 、止まら ない)、「混沌」とした様相を呈するもの。4 歳児組男子 2 例 (20\%)、 同女子 6 例 $(35 \%) 、 5$ 歳児組男子 1 例（ $7 \%$ ）、同女子なし。

混沌は 4 歳巟組に多く見られる。写真 $12 、 13$ 男 4 (6)の事例では単

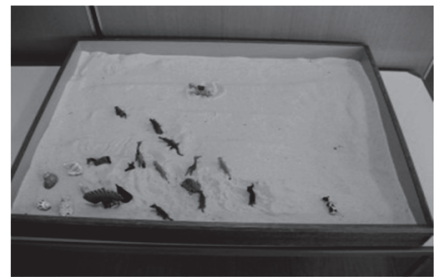

写真 4 女 4 (7)

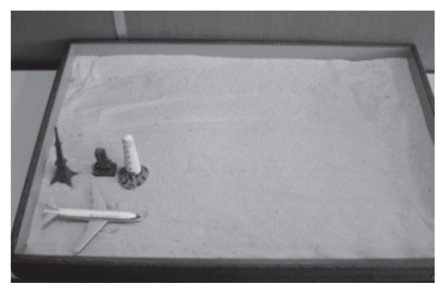

写真 8 女 5 (4)-1

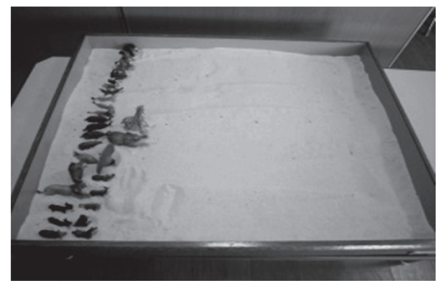

写真 12 男 4 (6)-1

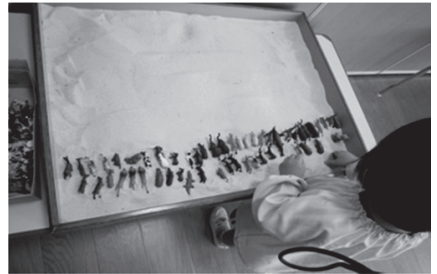

写真 5 女 48

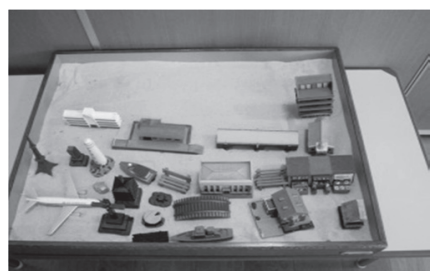

写真 9 女 5 (4)-2

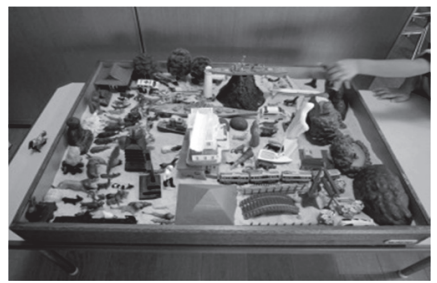

写真 13 男 4 (6)-2

に羅列的に並べるだけではなく、途中で動物を砂にめり込ませたり、 上から砂をかけたり、戦闘機を手に取り飛行させるなどの遊びも混 じっていたが、玩具を置いていくこと自体に熱中しだし、混沌とし た有様となった（写真 13）。写真 14 女 4 (11)-1 は、上記男子の事例 と同様に、羅列から始まり混沌に終わった作例である。途中で止ま らなくなり、棚の玩具を順にほとんど置いていくことになった（写 真 15 女 4 (11)-2）。4 歳児組では、例えば動物を全部置く、棚の特定 の段にあるものを全部置く、あるいは制限時間（約 1 時間）でやめ るように言うまで置き続けるといったことが顕著に見られた。

\section{2-2. 構造化の諸段階}

構造化：箱庭全体を見て、置かれた諸玩具が何らかの意味連関の 中、空間的に適切に配置されているもの。4 歳児組男子 1 例 $(10 \%) 、$ 同女子なし、 5 歳监組男子 4 例 $(27 \%)$ 、同女子 2 例 $(22 \%)$

写真 16 男 4 10は 4 歳児組では最も構造化された作例である。この 作品では初期にレールを並べる（項 16、最初にレール）。左下の工 事現場、中央を横切る線路と駅、右上病院と救急車、左上の神社と 鳥居といったように、意味のある「場」を構成している。また左下 のかなり広い「領域」では工事車両によって工事現場遊びがなされ た。以降こうしたまとまりの狭いものを「場」、比較的広いものを 「領域」と呼ぶことにする注 ${ }^{4)}$ 。「全体が明確に領域や場で構成さ れていることは構造化の一般的特徴の一つ」である。

なおこの作品では工事現場横に戦闘機があったり、線路より上側 の街中に「場違い」に 2 隻の軍艦があったりもしている（こうした ものを「場違い」と呼ぶことにする）。しかしたくさんの玩具を手 にとって遊びたがる園児の箱庭においては、構造化された箱庭とい えども場違いがあることが多い。

写真 17 男 5 12) は混沌的性格を残しているが、意味をもった様々な 場があり、また中央の中心的な領域は一匹のドラゴンに対して戦車 や多数の動物が対峙するという「テーマ」でまとめられている。こ

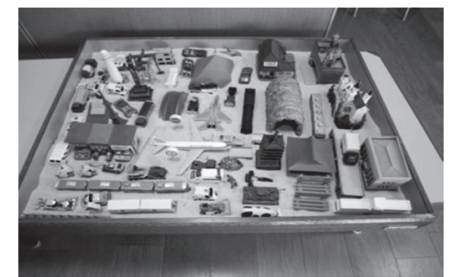

写真 6 男 4 (5)

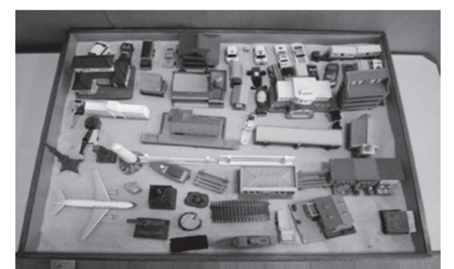

写真 10 女 5 (4)-3

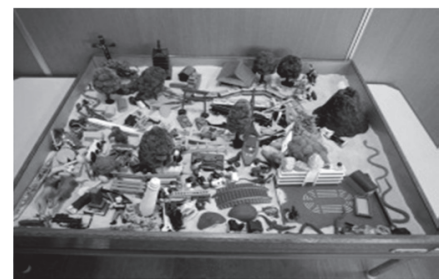

写真 14 女 4 (11)-1

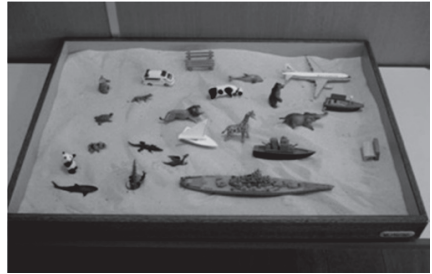

写真 7 男 58

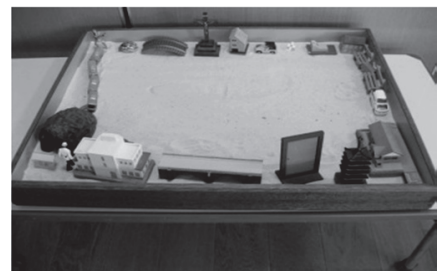

写真 11 女 4 9)

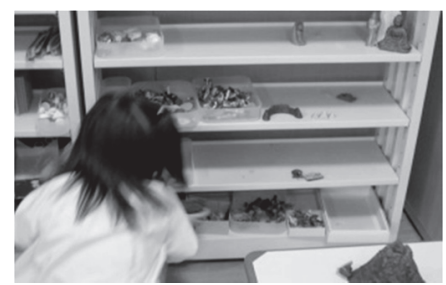

写真 15 女 4 (11)-2 


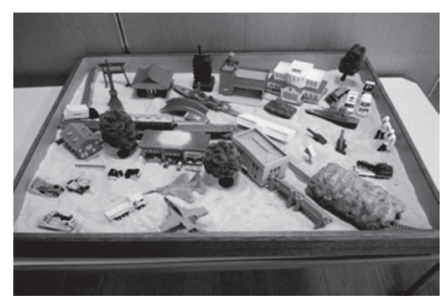

写真 16 男 4 (10)

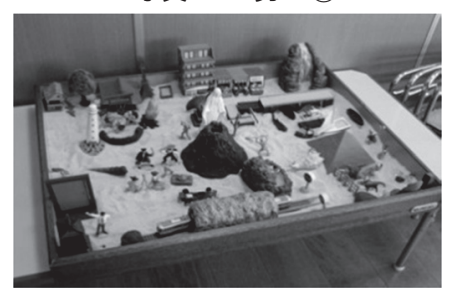

写真 20 男 5 (15)

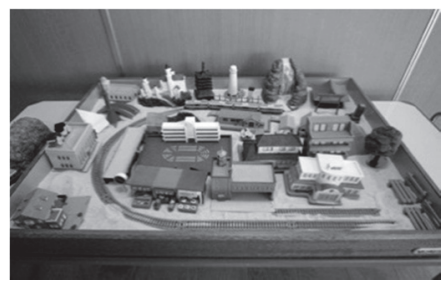

写真 24 男 4 (9)

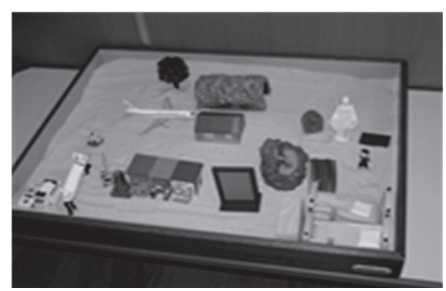

写真 28 女 5 (7)-1

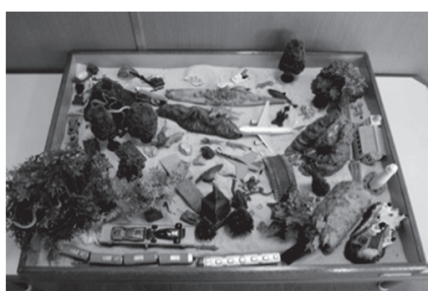

写真 17 男 5 (12)

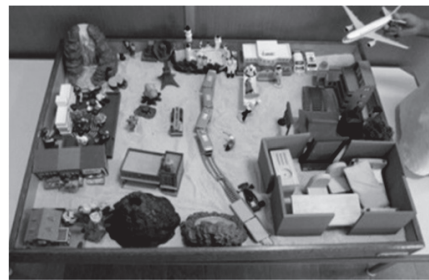

写真 21 女 5 (9)

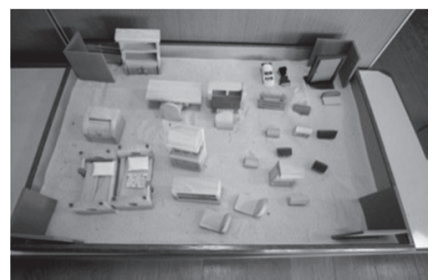

写真 25 女 4 (17)

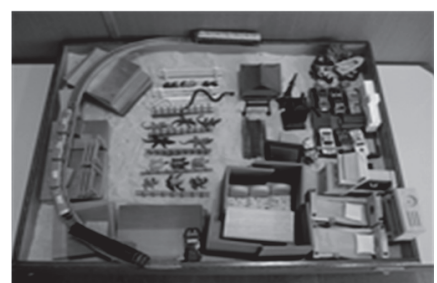

写真 29 女 5 (7)-2

うした「テーマ的まとまりも構造化の一般的特徵」と言える（前事 例写真 16 はこれほどテーマ性は表立っていないが、「工事現場のあ る町の風景」とでも言うことができよう）。

写真 18 女 5 8)では、左上の少年がサッカーをしている運動場や中 央下から上へ鳥居、神社、観音様、五重塔と並んだ宗教空間など、 多様な場をもつ町の風景から始めて、中央下に植物で囲われたお花 屋さんの領域が出現する。それを中心とするまとまった形の箱庭と なった。ただ終了前にお花屋さん部分にどんどん植物を詰め込み始 める。写真 19 男 5 (13)もレールと電車と駅で鉄道遊びをすることから 始める。水面を作ったり、山を作る。次に工事車両で工事現場遊び。 「箱庭楽しい」と言いながら遊ぶ。水面を環状につなげて水路とし、 船を回して遊ぶ。水路には太鼓橋をかけ、トレーラーを行き来させ る。遊びの展開の中で、それぞれの場所が意味のある領域となり、 全体で風景を構成するものとなっている。写真 20 男 5 (15は早い段階 で中心と四隅にものを配する構成ができる。その後、吟味して再配 置を繰り返しながら町の風景を構成していく(項 13、再配置、吟味)。 その中に海賊対海賊、騎士対騎士の戦い、神社を守る騎士たち等々 の場面を入れていく。また、そうした場面が可能なように、広場を 作ったり、場と場をつなぐ通路空間を既存の玩具を動かすことで作 っていく。すなわちこの作者の場合、単に戦いなど行為のイメージ （図）を作るだけではなく、その背景となる「地」的な空間を意識 して作り出している。項 14 の「空間設置」は、このように背景的な

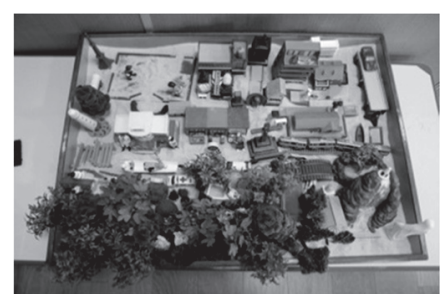

写真 18 女 5 8

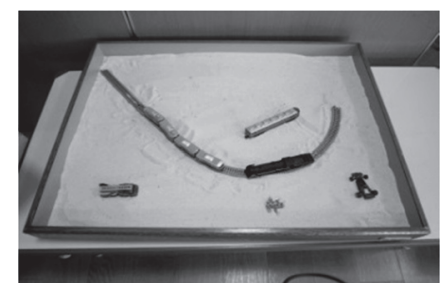

写真 22 男 4 8)-1

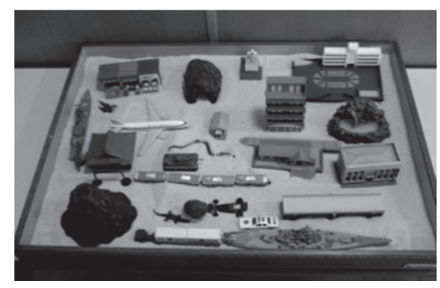

写真 26 男 5 (11)-1

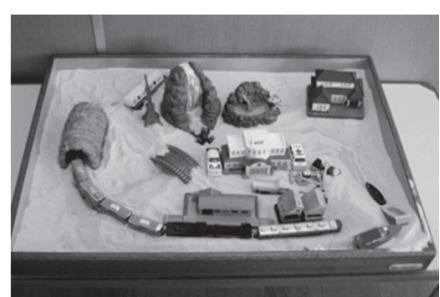

写真 19 男 5 (13)

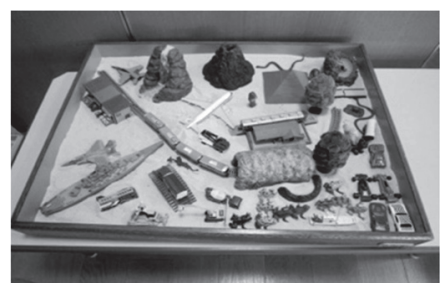

写真 23 男 4 (8)-2

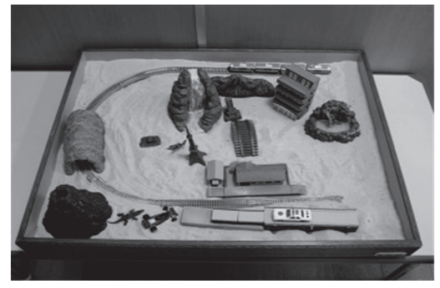

写真 27 男 5 (11)-2
「地」をわざわざ既存玩具を動かして作ったり、写真 19 の事例のよ うに砂で地形を造成したりする操作がある場合を表す。

写真 21 女 5 99は、まず中心と四隅に玩具を置くことからはじめ、 建物などを周囲におき「囲い」配置とする。右下の玩具をどけて、

そこに室内空間を作る。この室内空間が箱庭全体の中心的部分とな る。全体的に見ても各部分は意味のある場や領域として形成されて いる。後半で人物、乗り物、動物を使って演じる遊びをおこなう。

部分的構造化 : 羅列・混沌と構造化は両極として、それぞれには っきりと把握できる作品が存在するが、両者の間には中間的様相の 作品も存在する。羅列的、混沌的箱庭に構造化の要素が部分的、萌 芽的に存在している作品のなかで、骨格的なものがある程度見て取 れる箱庭を「部分的構造化」とする。4 歳児組男子 2 例 (20\%) 同女子 1 例 $(6 \%) 、 5$ 歳巟組男子 1 例 $(7 \%)$ 、同女子なし。

写真 22、23 男 4 8は部分的に構造化された例である。作り始めて すぐにレールをつなぐ（写真 22）。レールに SL や電車、トンネル を置いたり、近くに駅があったりと、いくつかの部分に意味のある 配置が出現している。しかし戦艦や飛行機などが周囲と無関係に置 いてあったり、全体的にも羅列的な傾向が強く残っている。写真 24 男 4 (9)部分的構造化の例で、これもレールをつなぐところから始 めた。建物は縦横配置的で羅列的な傾向が強く残っている。

写真 25 女 4 17は女子の例で、四隅に壁が建てられ、また左側には 家具が置かれ、内部空間的ではあるが、右側には小さな家々並べら れている。置かれた玩具は全体的に羅列的である。

テーマを見つけて構造化 : 初めは全くの羅列であるが、突然テー マを見いだし、作品が改めて内容のあるものに根本的に作り直され るもの。4 歳児組男子および同女子なし、5 歳児組男子 1 例 ( $7 \%$ )、 同女子 1 例 $(11 \%)$ 。

写真 26、27 男 5 (11)の事例では、前半は写真 $8 \sim 10$ 女 5 (4) と同様、 左下から右上へ機械的にどんどん置いていき、右上に達したところ 
で、空いた隙間に詰め込むといったものであった（写真 26）。とこ ろが、ある時点で棚にあるレールに目を留め、レールを置く。その 後、鉄道遊びに集中寸るなかで、羅列段階の多くのものが取り去ら れ、全体が意味のある玩具配置の箱庭（写真 27）となった。

写真 28、29 女 5 (7) も最初は左下から始まる羅列であったが、右下 にベッドが置かれると、その周りに室内空間が形成されていく。次い で右下の室内空間を確保したまま左半分は様々な形で外部の町の空 間が試される。さらに室内空間を充実させた後、それ以外をすべて 撤去し、左には新たに板積み木を使って高架線路が熱心に構築され、 室内空間を取り巻く外部空間が構成された。

\section{2-3. その他の事例}

以上はまとまった形となる箱庭の分類である。それ以外は「作ら ないなど」グループと「変転」グループに大きく分かれる。またこ の二つのグループともに、行為を箱の中でする者と、そこまで来ら
れず、棚の前に留まる者とがいる。棚の前に留まる園児はほとんど の時間棚側を向いており、観察者に対しては背中を向けている（項 1、棚の所）

作らないなど : 全く作らない、あるいはほとんど作らない事例や 玩具遊びだけが現れる事例。4 歳児組男子 2 例（20\%）、同女子 3 例（18\%）５歳览組男子 2 例（13\%）、同女子 1 例（11\%）

しばらくじっと玩具棚を見つづけ、少し玩具に触れるだけで帚っ てしまった園児が 4 歳児組女子に 1 名と 5 歳児組男子に 2 名いた。 写真 30 男 4 (1)は棚の前でしばらくもじもじした後、棚の前で戦闘機 や飛行機を手にとって、しばらくの間飛行遊びをして帰った例であ る（箱の位置は写真右下）。箱内の例としては、ほんのいくつか玩 具を箱におくだけで帰った者が 4 歳児組男子 1 名、同女子 2 名、砂 の中で乗り物を動かして遊んだだけが 5 歳児組女子で 1 名である。

変転 : その時々に何らかの形にはなるが、場面がめまぐるしく変

表 1 箱庭制作に見られた諸要素

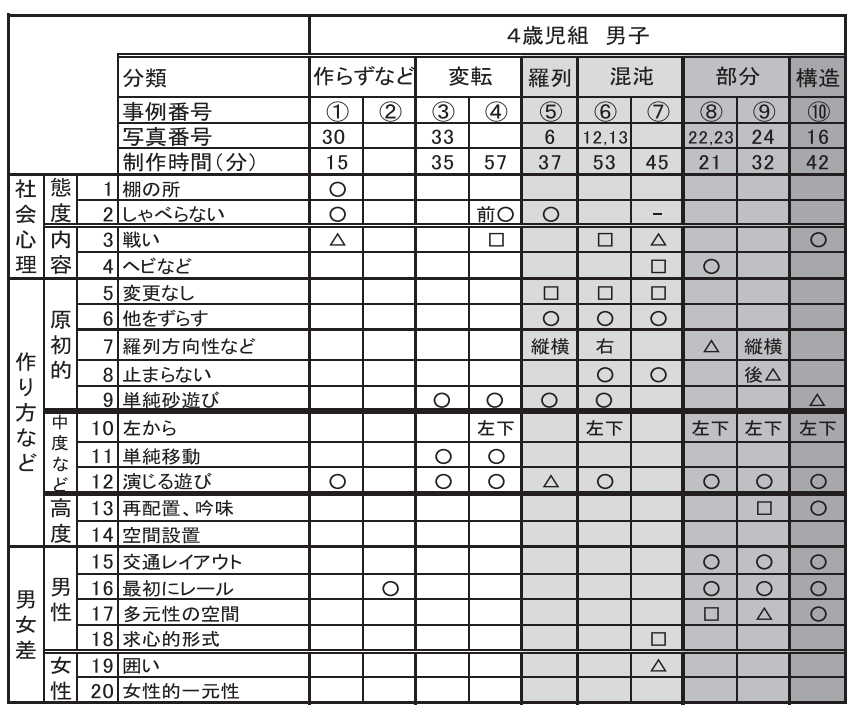
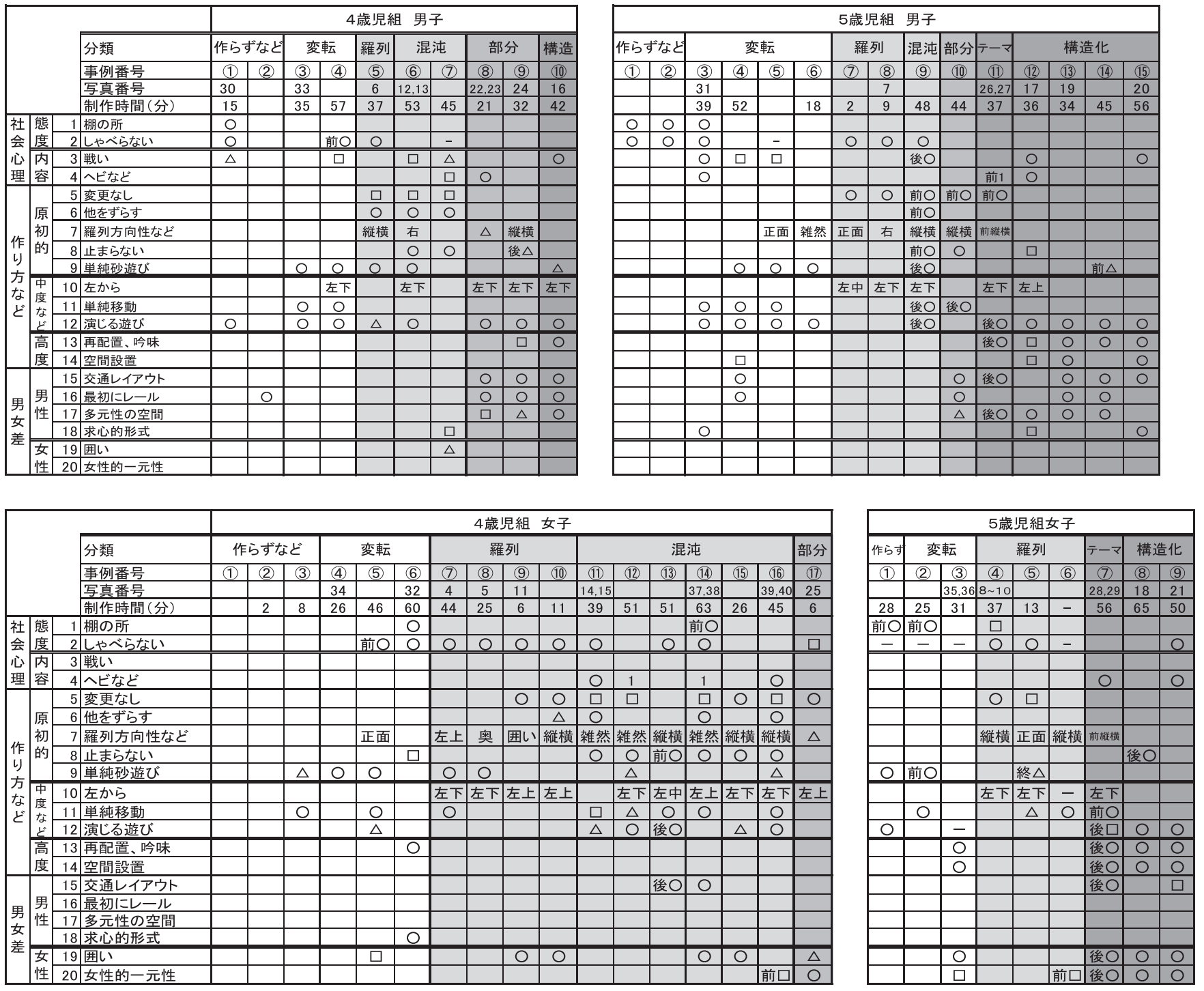

表中の分類の「作らず」は「作らずなど」、「部分」は「部分的構造化」、「テーマ」は「テーマを見つけて構造化」の略。

○はその特徵が明確に現れた場合、口は、完全ではないがほとんどその状態である場合、、は低程度に現れた場合を示す。

前O、後Oは前半、後半に（あるいは最初に、最後に）○状態であることを表す。なお記録がなく不明なものはーを記入した。 
化していくもの。4 歳児組男子 2 例（20\%）、同女子 3 例（18\%）、 5 歳坚組男子 4 例 $(27 \%)$ 、同女子 2 例 $(22 \%)$

棚の前の事例：写真 31 男 5 (3)へビやワニを両手に持って戦わ せたり、床にワニ軍団同士の対決場面を配置したりして遊び続けた。 写真 32 女 4 (6) は棚の上や棚の前で次々と様々な場面を作った。

砂箱内の事例 : 写真 33 男 4 (3) は次々といろいろな玩具を手に取 りその時その時に話をしながら遊ぶ。軍艦を砂に潜らせたり、砂を かけたり、砂で遊ぶ場面が多い。写真 34 女 4 (4)は、砂をかき混ぜた り、砂一面に手形をつけたりした後、おしまいに砂に顔を描いた事 例である。写真 $35 、 36$ 女 5 (3)は砂箱の中で構造化されたものを作り ながら、いくつもの場面に変転した例である。途中で中央部に囲い や家具による室内的空間が出現したりするが、それも変わってゆき 写真 36 になる。なお变転には創作行為の発達段階とは直接関係な く、写真 33 のような原初的段階のものから、写真 35、36のような 構造化の進んだ段階のものまで様々である。

\section{3. 構造化された作品と男女に普遍的な空間イメージとの関連}

男子の構造化された作品のうち写真 20 男 5 (15)の 1 作品を除き、残 りの写真 16 男 4 (10、写真 17 男 5 (12、写真 19 男 5 (13)、写真 27 男 5 (11)-2 は全て、本文の $1-2$ で述べた、移動・侵入的、外部的、多元 的といった特徵をもつ多元性の空間である（項 17、多元性の空間）。 部分的構造化の作品にも多元性の空間の萌芽が見られる。一方の写 真 20 は戦い・対決的な場面があちこちにちりばめられており、全体 としても中心に凸的な火山があり、図 1 の求心的形式の男性的一元 性の空間イメージ（項 18、求心的形式）と関連する。この事例は、 岡田天理資料では小学 3 年段階で多数現れた戦いのイメージ（写真 3 ) が、年齢的に見て早い段階で現れた例と見なすことができる。

女子の構造化された作品、写真 18 女 5 (8)、写真 21 女 5 (9)、写真 29 女 5 (7)-2 は、住人的、内部的、内包的、一元的な女性的一元性の

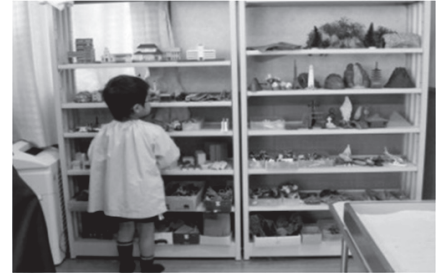

写真 30 男 4 (1)

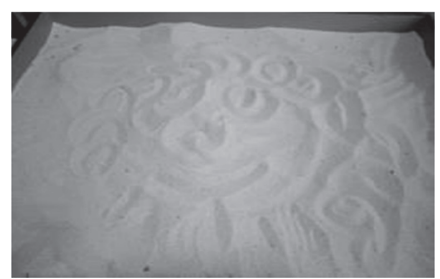

写真 34 女 4(4)

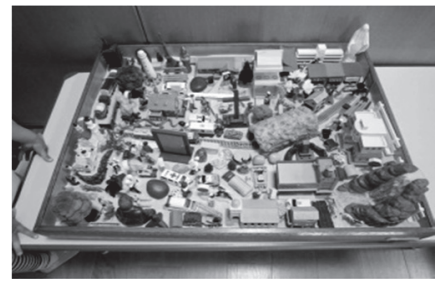

写真 38 女 4 (14)-2

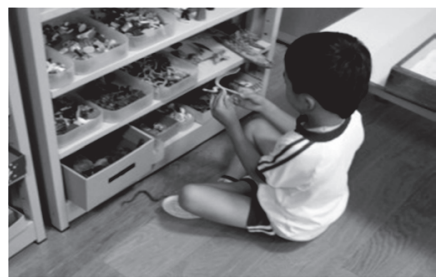

写真 31 男 5 (3)

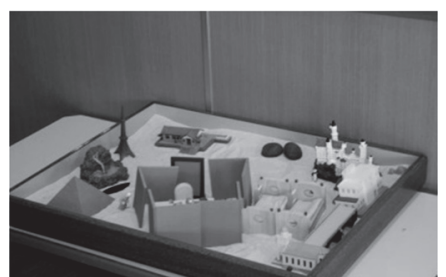

写真 35 女 5 (3)-1

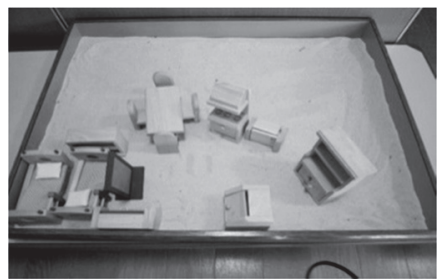

写真 39 女 4 (16)-1
空間が中心となっている。写真 18 では下側のお花屋さんの領域が女 性的一元性の空間であるが、それができると、その場所を作った本 人自身が、どんどんそこに引きつけられていった。写真 21 では全体 の街の風景が女性的一元性的空間であり、右下の室内空間も女性的 一元性という二重の構造をもつ。写真 29 は前半全く羅列的であった のが、途中で右下に室内空間（女性的一元性の空間）が確立される と、それが核となって全体が構造化された。女性的一元性の空間之 分類できる箱庭作品のうち、女性的一元性の空間と周囲の外部空間 という構成をとるものも多いが、保育園児の作品ではほとんどそれ であり、家具で作られた室内空間と外部空間というかたちであった。 項 20 で示すように女子で構造化された作品は全て女性的一元性の 空間である。また部分的構造化の段階（写真 25 女 4 (17)）でもその傾 向が見て取れる。

男女差についての補足：男女差については、構造化の段階で男子 の多元性の空間、女子の女性的一元性の空間といったはっきりした かたちをとっているが、それ以前にも違いの兆候は存在する。

女子の囲いから始まる作例など : 先述のように 4 歳児組女子では 明瞭な囲いを作ることから始めた園児が 4 名（24\%）いる（項 19、 囲い）。写真 11 女 4 9は囲いだけで終わった例だが、他の 3 事例で は囲いができた後、中にどんどん置いていき、全体が縦横形式の羅 列や混沌となった（項 8 ）。写真 37 女 4 (14)-1 はこの時点で終われ ば女性的一元性の形式をもった町の風景だが、さらにどんどん置い てゆき、結局写真 38 女 4 (14)-2 の混沌の状態となった。こうした囲 いは女性的一元性の空間の内包性、内部性の先駆的な現れであろう。 一方このような囲いを作る例は男子では一例もないとみなされるも のであった注5)。写真 39 女 4 (16)-1 は住人的で、内部的、一元的であ り、室内空間としての女性的一元性風の様相を示す。しかしこの事 例も制作はこれで終わりとならず、どんどん詰め込んでゆき、写真 40 女 4 (16)-2 の混沌状態となった。

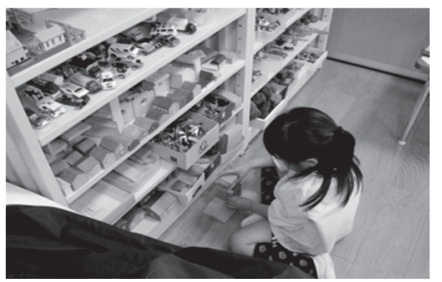

写真 32 女 4 (6)

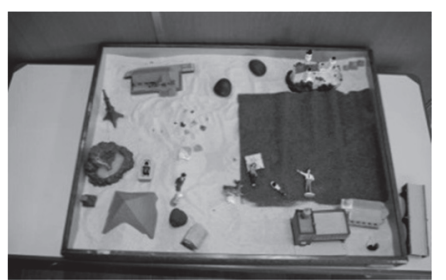

写真 36 女 5 (3)-2

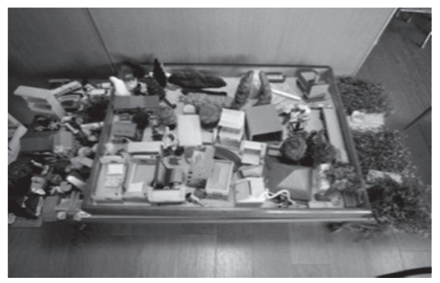

写真 40 女 4 (16)-2

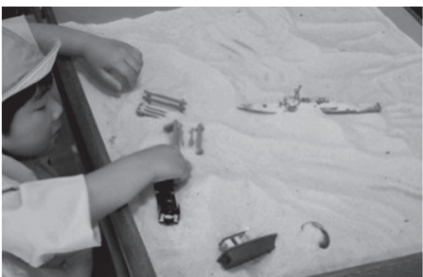

写真 33 男 4 (3)

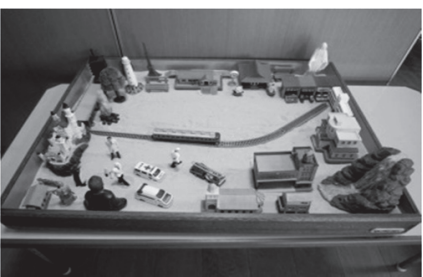

写真 37 女 4 (14)-1

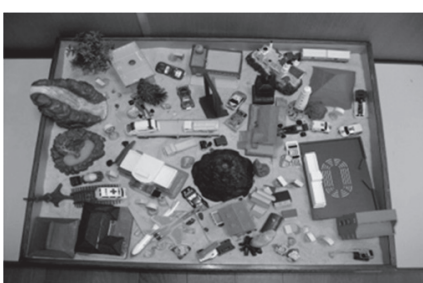

写真 412012 年 5 歳児組男子 
男子のレールから始まる作例 : 同じ 4 歳児組で男子の部分的構造 化の 2 作品（写真 $22 、 23$ 男 4 8)、写真 24 男 4 (9) はどちらも最初 の段階でレールをつないだ（項 16、最初にレール）。

\section{4. 創作行為の発達と遊びの諸形態の発達}

羅列・詰め込み遊び : 羅列といえども、先に述べたように、そこ には寸でカテゴリー的まとまりや、列状や向きをそろえるなどの形 態的な秩序がある。

羅列の延長として、特に 4 歳児組で玩具をどんどんと置いてゆき 止まらなくなることが多く（項 8、止まらない）、混沌とした様相 を呈する。写真 12、13 男 4 66の事例（制作時間 53 分）では、開始 30 分頃、置くことが止まらなくなってきたので、立会人である観察 者が「もうこれくらいでおしまいにしよう」と話しかけたところ、

「いやや」と返事をし、さらに 20 分余り玩具を置きつづけた。写真 39、40 女 4 (16)の事例（45 分）では、写真 40 を作り終わった後「も う一回する」と言って観察者を驚かせた。混沌となる事例では、制 作時間の長さを含めてこれらの事実は、どんどん置いていく行為自 体が自律した強い欲求として存在していることを示している（一方 で写真 4 女 4 (7)、写真 5 女 4 (8)の事例で見られた、最後に並べた玩 具を砂も万ともにかき混ぜる行為は、おしまいにすること、リセッ ト寸ることといった欲求も同時に存在していることを示している）。

写真 37 女 4 (14)-1 や写真 39 女 4 (16)-1 は、最初は女性的一元性風で あったのに、結局写真 38 女 4 (14)-2、写真 40 女 4 (16)-2 の混沌となっ た。この 2 例および同様の経過をたどった事例女 4 (15)の制作時間は 63 分、45 分、26 分である。すなわち彼女たちはたくさんの玩具を 前にして、ずっと遊んでいたかったのであり、それがこの年齢段階 では女性的一元性のイメージを充実、完成させる方向ではなく、様々 な玩具を手に取り、集め、並べ、詰め込んでいくことへの熱中とな ったのである。一方 4 歳児組で混沌とならず、女性的一元性の傾向 をもつ作品として残ったものは写真 25 女 4 (17)の 1 事例のみで、制作 はわずか 6 分で終わっている。

単純な砂遊び：4歳児組の段階で原初的に見える要素として羅列 の他には単純な砂遊び（項 9 ) が頻繁に現れる。砂に手を突っ込む、 砂をたたく、砂をかき混ぜる、乗り物など玩具を砂にめり込ませな がら動かす、玩具を砂に埋める、並べた玩具の上にすくった砂をふ りかける、等々である。羅列的に玩具を置く場合も、砂に押し込む ように置くことが目に付く。これらの行為はショベルカーで砂をす くってダンプにいれるとか、背景としての山や川を砂で作るといっ たような意味のあるものではなく、砂にさわることの手触りや手応 えなどの感覚やその行為自体を目的としている（あるいは楽しんで いる）ように見える注 6)

演じる遊び：羅列・詰め込み遊びや単純な砂遊びに次ぐ段階のも のとして目にとまるものは「演じる遊び」（項 12）である。例えば 4 歳児組の写真 12、13 男 4 (6)の事例では、羅列、詰め込みの途中に 戦闘機を手に取り飛行を演じる遊びをおこなった。演じる遊びは羅 列段階で既に現れ、以降の構造化の段階でも存在し続ける。

構造化以前の段階のものとしては、写真 30 男 4 (1)、写真 31 男 5 (3)、写真 33 男 4 (3)の事例の他、ショベルカーで砂をすくってダンプ カーに積み込むといった例などがあった。構造化の段階では、例え ば男子で電車などの乗り物遊びが頻繁に現れる注7)。そして構造化以
前の演じる遊びの段階と構造化された箱庭の段階の違いは何かとい うと、後者は物理的に「背景が実体化されている」という性格をも つことである。すなわちレールや道路、水路、さらにそれらが巡る 街並みや景観などが現れているのである。

ところで演じる遊びのみが現れ、背景（「地」的、空間的なもの） が作られない段階（構造化以前）について考えてみると、その場合 においても、例えば戦闘機なりショベルカーなりがもつ役割、どの ような場所や状況において、どのような働きをするかという筋書 き・意味連関は頭の中で背景として形成されているはずである。し かし構造化以前の演じる遊びの場合はそうした背景は実体化されな い。つまり構造化された箱庭は「演じる遊び」と「背景の実体化」 が合体したものと考えることができるのである。

「背景の実体化」とは空間的性格をもつことがらである。そこで 次に空間的感覚の発達を見ていきたい。

場の増加、空間的感覚の萌芽 : 同じ混沌とした作例でも、4 歳児 組のものは機械的に隙間なく詰め込む結果（例えば縦横的羅列）、 どこも均質で単調な印象であるのに対して、5 歳児組では縦横的羅 列形式は減って、それぞれの場所が差異化し、あちこちに場あるい は「場的な空間」のあるものが増える。場的な空間とは、場とまで は言えないものの、動物や兵隊、乗り物、工事車両等々が羅列的で はあるがまとめて置かれたところである。5 歳児組では建物の間な どの隙間が場的な空間となっている場合も多い。

写真 $41^{\text {注 }}{ }^{8}$ は混沌と構造化の中間的作品であるが、作り始めは幾 分多元性の空間の構成が現れていた。しかし次第に玩具が詰め込ま れてゆき、混沌に近づいていったが、そこここの隙間が交通空間の ような場的空間として残った。つまり 4 歳児組の羅列・混沌では物 の集まりばかりに目が向けられていたが、5 歳児組の羅列・混沌で は隙間や空間的なものが見いだされているのである。空間的感覚の 萌芽といえる。なお 4 歳児組でも写真 23 男 4 8-2 のような部分的 構造化段階以降の作品では、場や場的空間は明確に現れている。

\section{全体的な空間的感覚（全体的構成や全体的骨格）の出現と世界像}

遊び：構造化された作品には全体にわたる領域的分節化や領域相互 のネットワーク化などの空間的な把握が見て取れる。男子では構造 化された作品のほとんどでレールや乗り物が使われているが、この ことについて考えると、例えばレールを初めに置く場合、そこに自 ずと骨格が出現する。するとその周囲にいくつかの領域や場を見い だすことはごく自然な流れとして生じうる。構造化を成立させる全 体的な空間的感覚の発達的出現は、骨格の構築あるいは領域的分節 化の両方の側面をもち、そのどちらの形でも現れうる。（ただし全 体的な空間的感覚が十分に発達していない段階でもレール＝骨格的 要素を使用寸る場合はあるわけで、写真 24 男 4 (9)のように縦横的な 羅列的傾向が強く残る作例はそうした例といえるだろう。)

さて構造化を成立させる全体的な空間的感覚には明確な枠組が見 て取れる。「3. 構造化された作品と男女に普遍的な空間イメージ との関連」で述べたように、構造化された作品は、男子においては 「多元性の空間イメージ」や「男性的一元性の空間イメージ」、ま た女子では「女性的一元性の空間イメージ」といった形式をとって 現れてきているのである。

多元性の空間イメージの基礎にある構造は、改めて述べるなら、 写真 1 のように、複数の何らかの領域や物体が連続的あるいは非連 
続的に存在しており、その間を何か（主体的なもの、客体的なもの、 単数、複数など様々) が動いているといったイメージである(移動・ 侵入的、多元的、外部的、その他に非対称性や、水平に広がってい く性質などをもつ）。空間的感覚の枠組はこのような構造をもつ。 それは受け皿あるいはひな形のようなものであり、そこにしかるべ きものごとが盛り込まれていくことで外界の認識が進んでいく枠組 （=意味連関を定着させる枠組）である。男子の場合、このひな形、 受け㿼にぴったりと当てはまるものであるレールや電車、道路や乗 り物といったもの（移動・侵入性）に自ずと興味が引かれ、またそ れらが引き金（鍵刺激）になってシステムは動きだし、街や風景の 広がりなど（多元性、外部性）がはめ込まれてゆく。そしてこの枠 組に沿った構造化した箱庭が実現される。女子では家具などをきっ かけに周囲に室内的空間が広がり、箱庭全体の中の中心的な空間と なる。そこは人々が楽しげに暮らしているイメージである女性的一 元性の空間であり、その出現を契機に、空想や連想が展開し、遊び が繰り広げられ、全体として構造化された箱庭となる注9)。

こうした演じる遊びと背景の実体化が統合された「想像的情景を 作る遊び」を、ここで改めて「世界像遊び」と呼ぶことにする注 ${ }^{10)}$ 今ここにないものを思い描く能力は想像力であり、創作する能力で あるが、それは象徵的なもの（玩具などの物体、あるいは記号、言 葉など）を適切に配置して何らかの情景をつくり出す（意味連関の 定着）能力である。そしてそれは構造化された箱庭の制作（=世界 像遊び）の能力である。またその枠組を空間的側面から見ると多元 性の空間イメージ、女性的一元性の空間イメージ等の基本的空間イ メージとなると考えられる。

このように多元性の空間イメージなどの基本的空間イメージが、 そこに意味連関が定着していく原型的な枠組であるという考えを裏 付けるものとして次の事実を挙げることができる。羅列の段階では 変更もなく置いていく（項５、変更なし）、あるいは詰め込むため にずらす程度（項 6 、他をずらす）であったが、構造化の段階では、 相互的、空間的関連性を考慮した取り替え、置き直しなどの場所・ 配置に関する試行錯誤、吟味の操作が現れる (項 13、再配置、吟味 注 11)）。これら再配置、吟味の操作は意味連関を定着させる操作で あるが、また空間的な相互関係や場所の感覚といった認識を示寸も のでもある。すなわち、これらの操作と多元性の空間イメージなど 基本的空間イメージの出現とは同じことがらの二側面なのである。

同じ構造化された作例とはいえど、写真 16 男 4 (10), 写真 17 男 5 (12、写真 18 女 5 (8)の 3 作品が場違いや、前段階の混沌的な性格を残 しているのに対して、写真 19 男 5 (13)、写真 20 男 5 (15)、写真 21 女 5 (9)の 3 作品は余計な物が存在しない明確なものとなっている。写真 19 の砂の造成による運河づくりや、写真 20 での登場人物が行動す るための場所を広げたり、通路のための空間を開くというような空 間そのものに関わる操作（項 14、空間設置）がより強くでる場合、 こうした明確な空間的な領域の認識が取捨選択の作用を伴い、「場 違い」をふるいわけ、排除することになるのかもしれない。

基本的空間イメージが意味連関を定着していく枠組であり、空間 的認識・操作と一体であることは、「テーマを見つけて構造化」の 2 事例（写真 26、27 男 5 (11)よび写真 28、29 女 5 (7)）でも見て取 ることができる。全くの羅列的であったものが、男子ではレールを 置くことをきっかけとした多元性の空間として、また女子では出現
した女性的一元性の空間が中心を占めるものとして、構造化が劇的 かついきなり出現しているのである。

すなわち、この事実はすでに潜在的に育っていた枠組のシステム にスイッチが入ったというふうに考えることができるのである。つ まり多元性や女性的一元性などの基本的空間イメージは、成長に伴 い学習により徐々に形成されていくものではなく、生まれもったシ ステムとして、ある時期に最初から全体として生じて来るものであ るということである。そのことは男女では全く別の形式で、かつ男 子は男子で共通、女子は女子で共通であるという事実が示している。 またこれは構造化の段階とそれ以前の羅列・混沌の段階の間に、あ る種の不連続があるように感じる理由でもあろう。

このような形で想像力や創造力は、われわれがもつ認識システム の枠組（空間的にはこれらの空間イメージ）に支えられており、か つ規定されているといえる。これまで基本的な空間イメージとして きたものは、はまさに「原型的」空間イメージと呼べるものであっ たわけである注 ${ }^{12)}$ ここういう考えを強化するものとして、リラック スしてとても楽しそうに遊んでいるときにこうしたイメージが自然 と現れて来るという事実を指摘することができる。

写真 17 男 5 (12、写真 18 女 5 (8)は混沌的衝動が残っており、様々 な片隅的場に満ちた作風となっている。このように構造化の枠組(原 型的空間イメージ) は、混沌的傾向に半ば埋もれて存在する場合が ある。写真 41 は枠組がほとんど埋もれた例であり、4 歳児組女子の 写真 38 女 4 (12)-2、写真 40 女 4 (16)-2 の事例は最初に枠組は現れかけ たものの、完全に埋もれてしまった例といえる。

\section{5. 心理・社会的発達と箱庭制作}

ほとんどの園児が箱庭を楽しんだと考えられる。それは時間の長 さに表れている。一方で作らずにすぐ帰ってしまう園児がいた。ま た棚の前に留まり、観察者に背を向けたままの園児もいた。見知ら

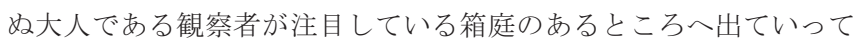
何かを作るということは、舞台に立ち、人前で自分を表現すること と同じである。子どもの成長過程は、乳児と母親、家族との関係か ら始まり、外部社会に向かって自分の心理・社会的なわばりを一歩 ずつ勝ち取ってゆく過程であるが、そこには前向きな気持ちだけで はなく、ほぼ同じだけの不安が存在する。そして外に向から気持ち と不安のバランスは一人一人異なっている。そのバランスが内向的 に傾く園児は箱庭の所まで出て来なかったりするわけである。

写真 31 男 5 (3)の事例で園児はずっと棚の前にいて遊び続けた。ワ ニとワニの戦い、カメ群とワニ群の戦い、へビ群とへビ群の戦いな ど、大半の時間を対決、戦闘の場面を演じることに費やした。写真 30 男 4 (1)の園览は棚を向いて立ちつくしていたが、終わり近くに戦 闘機を手に取りこちらを向き、飛行を演じる遊びをおこなった。写 真 32 女 4 (6)では、棚の上と棚の前にいくつかの構造物を作ったが、 最後には一匹のコアラに対して多数の動物たちが求心的に向き合う 場面を作った。それは対決的意味をもつ求心的形式の男性的一元性 の空間イメージである。

外部世界に向かって心理・社会的なわばりを広げていく過程は対 決的、攻撃的力動の上にあるが、これらの事例に現れている攻撃的、 戦闘的なイメージは、そのための心理的な助走や準備運動そのもの といえる。なお棚の前に留まる園児は全員喋らないという特徵があ 


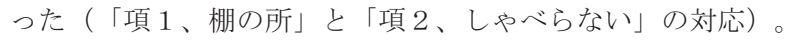

岡田天理資料の小学 3 年男子では過半が写真 3 のように戦いをテ 一マとした箱庭となっている。今回保育園の段階では全面的に戦い の場面となったものは写真 20 男 5 (15)の事例以外なかったが、男子で は「項 3 、戦い」で示寸ように、かなりの頻度で戦いのイメージは 現れる（戦闘機、戦車、戦艦の使用や戦いの場面を演じるなど）。 一方女子では戦いのイメージは出て来ないが、写真 14 女 4 (11)-1 の ようにへビが使われる箱庭はかなりある（項 4 、へビなど。なお表 中の 1 は 1 匹だが、目立つかたちで置いてあったもの）。箱庭玩具 には極彩色のへビやカエルが置いてあり、女子でそれらがわざわざ 使われる様子は男子の戦いのイメージと同じような心理・社会的意 味があるように思われる。例えば写真 21 女 5 (9)では後半の一時へビ が多数室内空間のところに持ち込まれ遊ばれた。作者は表情豊かに 演じる遊びはおこなうものの、終わりまで一言も喋らなかった。つ まり彼女はへビを観察者の前でもて遊んでみせることで、観察者 $(=$ 外部社会の大人) に話しかけるための助走をしていたと考えられる。

写真 19 男 5 (13)園児は、初め小さな声でささやくようにしか話せ なかったが、遊びに夢中になり、「箱庭、楽しい」と言いながら、 だんだん大きな声で話をするようになった。遊びに夢中になること で、幾分すくんでいた状態から解放されたといえよう。写真 $28 、 29$ 女 5 (7)の「テーマを見つけて構造化」の事例では長時間かけて（56 分）箱庭を作り上げたが、本児は何かをやり遂げたという表情で、 満面の笑みを浮かべて保育室へ戻っていった。これらは観察者とし ても感動的な体験である。彼らは、実際の箱庭療法と同様、心理・ 社会的な成長過程を少しなりとも進めたと思われる。

子供の遊びは安心してリラックスした状態でないと発現しない。 そのことは 5 歳児組で羅列的作品を作った園児（写真 7 男 5 8)、 写真 8 10 女 5 (4)および男 5 (7)、女 5 (5)の例）が全員しやべらない ということにも現れている（女５（6)は不明）。写真 8～10の作者は ほとんどの時間棚の前にいて観察者に背を向けていた。彼らには潜 在的に構造化した作品を作る能力がすでに発達している可能性があ るが、緊張で楽しく遊ぶなかったことで羅列の箱庭しか作らなかっ た考えることができる注 13)。一方写真 31 男 5 (3)や写真 32 女 4 (6)の 事例では観察者に背中を向けたままだったが、長時間遊んでいる。 ある程度リラックスできる片隅空間を見つけて遊んだと言える。

その他に心理・社会的意味をもったことがらとして、多くの園児 で箱庭を左から置き始めたことをあげることができる（項 10 、左か ら）。箱庭療法では左を内界あるいは無意識の側、右を外界、意識 の側とする。左から右に置いていったということは、自分の世界か ら外の世界へと向かっていったことと同じと考えられる。

\section{6. 結語 まとめ}

箱庭における創作行為の発達過程について、ごく大きく捉えると、 羅列・混沌の段階と、諸玩具が意味をもって空間的に適切に配置さ れる構造化の段階に分けることができた。

羅列は原初的段階であるが、最も雑然とした羅列の例でも、例え ば動物ばかりを使うといったまとまりを見ることができる。これは カテゴリーによる分類化がわれわれの認識の最も基本的要素の一つ として備わっていることの表れであろう。羅列段階では形態的に、 列状に並べる、方向性をそろえる（正面向き、奥向き、右向き、左
向き、縦横向きなど）が頻繁に現れる。また特に 4 歳児組では羅列 が止まらなくなり、詰め込むことに熱中して、混沌とした様相を呈 することが多(注 14$)$ 。羅列段階で見られるこれらのカテゴリー分け や形態的秩序化および引き続いて起こる詰め込みなどは、以降の発 達段階での、対象に興味をもって手に取ること、それを何らかの形 で認識すること（分類・整理すること）、収集、所有すること等々 の行為の基底にある自律性を備えた基本的要素の現れと考えること ができる。また形態的秩序化は構造化の段階で表に現れることはな くなるが、人間の世界像形成の最も基本的要素であり、われわれが 意識的、無意識的に感じる秩序感の基盤として後の成長段階でも存 在し続けていると考えることができる注 ${ }^{15)}$ 。

箱庭に現れる砂を使った遊びは様々であるが、羅列段階で頻繁に 現れる「単純な砂遊び」は、さわってみる、感触や手応えを味わう といったように行為自体を楽しむという側面がある。これらの行為 もまた、自分を取り巻く諸々のものを認識するために備わった基本 的行動様式の現れなのであろう。

次いで、自動車が動いている場面を演じるといった「演じる遊び」 が現れて来る。演じる遊びにおいては、どのような場所や状況にお いてそれが動くなり、働くなりするかといった背景的意味連関は当 人の頭の中には存在するわけだか、構造化以前の段階での演じる遊 びにおいては、背景は実際の物理的なものとして箱庭につくられて いない。そうした次第で、構造化された箱庭制作は演じる遊びと背 景の実体化が合体したものと考えることができる。背景とは舞台の ようなものであり、空間的性質をもつ。すなわち構造化は空間的認 識能力および空間的操作能力と一体である。なお空間的に構造化さ れた箱庭作品出現に先だって、場や場的な空間が増えるといった空 間的感覚の萌芽が見られる。

男女の差異に関しては、構造化以前の段階では、構造化において 見られる男女の特徴がいくらか先駆的に現れているという程度であ るが、構造化の段階では箱庭の空間的形式に関する男女差は著しい。 構造化された作品として出現したもの全てが、男子では多元性の空 間イメージ（一部は年齢的に次段階の男性的一元性の空間イメージ の要素をもつ）、女子では女性的一元性の空間イメージの形式をと るものであった。つまり構造化した作品は一番最初からいきなり「原 型的空間イメージ」という完成された形式をとって現れてくる（も し完成形で現れてくるのではないとしたら、もっと男女の要素が混 じり合ったり、あるいは反転したりしたかたちで構造化が現れてき てもいいはずである）。それらのイメージは空間的に構造化された 箱庭作品を成立させる枠組みであり、人間男女の世界認識において、 そこにしかるべき様々な内容が盛り込まれるひな型と考えられる

（それは思考そのものの枠組とも密接に関係寸る）。これら原型的 空間的イメージには、コンラート・ローレンツ以来の言葉を使うな ら、「生得的」な要素が多分に含まれていると言うことができよう。

\section{謝辞}

実験に協力してくださった社会福祉法人明石恵泉福祉会、第二恵 泉保育園の園長先生をはじめ職員の方々、また箱庭で遊んでくれた 多くの園児の皆さんに改めてお礼を申し上げます。 


\section{箱庭研究に関する主な既発表論文}

i ）坂戸省三 : 創作・表現行為および空間的表現の様態とその意味の箱庭療 法を通じての考察、ーライフ・サイクルと空間のイメージ構成に 関する研究 第 1 報一、日本建築学会計画系論文報告集、第 367 号、 pp.80-90、1986.9

ii）坂戸省三：男女それぞれにおける空間性の発達過程、一ライフ・サイ クルと空間のイメージ構成に関する研究 第 2 報一、日本建築学会計 画系論文報告集、第 377 号、pp.97-105、1987.7

iii）坂戸省三：男女の空間的諸特性と世界像の形成、一ライフ・サイクル と空間のイメージ構成に関する研究 第 3 報一、日本建築学会計画系 論文報告集、第 402 号、pp.107-118、1989.8

iv ）坂戸省三：人間における世界像形成の生物学的基盤について、一ライ フ・サイクルと空間のイメージ構成に関する研究 第 4 報一、日本建 築学会計画系論文報告集、第 421 号、pp.111-120、1991.3

v ）坂戸省三 : 人間における諸空間性の生物学的基盤について、一ライフ・ サイクルと空間のイメージ構成に関する研究 第 5 報一、日本建築学会 計画系論文報告集、第 435 号、pp.127-136、1992.5

vi ）坂戸省三：トルコ人と日本人の箱庭制作実験事例に現れた空間的特徵 の比較考察 一空間イメージの文化的差異に関する心理・社会的分析 その 1 -、日本建築学会計画系論文集、第 520 号、p.334、1999.6

vii）坂戸省三：箱庭制作実験事例に現れた空間構成における日本的特徵と 大陸的特徵の比較考察 - 空間イメージの文化的差異に関する心理・社 会的分析 その 2 -、日本建築学会計画系論文集、第 532 号、pp.275-282、 2000.6

viii）坂戸省三 : 空間構成におけるいわゆる日本的特徵の心理的背景につい て - 空間イメージの文化的差異に関する心理・社会的分析 その 3 一、日本建築学会計画系論文集、第 552 号、pp.335-342、2002.2

ix）坂戸省三：女性の箱庭作品において人類共通に見られる空間イメージ とその特徴について、日本建築学会計画系論文集、第 560 号、pp.297-304、 2002.10

x ）坂戸省三 : 大陸文化圈男子被験者の箱庭作品に共通して現れる空間的特 徵と彼らの世界像について - 空間イメージの文化的差異に関する心 理・社会的分析 その 4 -、日本建築学会計画系論文集、第 572 号、 pp.185-192、2003.10

\section{参考文献}

1）エリクソン、E.H.、近藤邦夫訳 : 玩具と理性一経験の儀式化の諸段階一、 みすず書房、p.42、1981

2）エリクソン、E. H. 、仁科弥生訳 : 幼児期と社会、みすず書房、1977

3）岡崎甚幸、柳沢和彦、難波恵美：居住空間構成法と幼稚園児、日本建築 学会計画系論文集、第 518 号、pp.313-320、1999.4

4）岡崎甚幸、大井史江、山口直子、浦崎寿輝 : 居住空間構成法と知的障害 児、日本建築学会計画系論文集、第 496 号、pp.237-245、1997.6

注

注 1) 実験は、2011 年 5 月から 7 月に 5 歳児組を対象に、翌 2012 年 4 月から 6 月に 4 歳児組を対象に行った。実験担当は、河内が 4 歳児組男子(7)、 (10、4 歳児組女子(1)、(7)、(9)、(12)、(15)の計 7 名、その他の学生が 5 歳児 組男子(5)、5 歳児組女子(1)、(2)、(3)、(6)の計 5 名をおこない（丸数字は 表 1 の事例番号)、それ以外の 39 名は坂戸が行った。表 1 は以上の作例。

5 歳児組に関しては 2012 年にも河内が実験しているが、本稿では坂 戸が多数の実験をした 2011 年の 5 歳児組を主な論述の対象とする。そ の他 2011 年 3 月末に卒園間際の園児を対象とした実験や、河内による 2 回目の実験、ブラジルでの実験などをおこなっている。

注 2) 岡田康信（京都大学名誉教授、前日本箱庭療法学会理事長）が天理大学 在職中におこなった箱庭の資料。幼稚園児から高校生までの実験は 1974 〜1976 年、大学生に対しては 1977〜1982 年におこなわれた。

注 3) 本稿で示した男女の空間的傾向のうち、男子の移動・侵入的、外部的、 女子の内部的、内包的という特徴は、エリクソンが少年少女を対象とし た玩具類で場面を作らせる実験において、性器的様式と関連させて論じ ている（参考文献 2、pp. 117-128）。その他の多元的、一元的、住人 的などの特徴のとらえ方は筆者自身の箱庭観察によるものである。

注 4) 岡崎らは参考文献 3 で「場」、参考文献 4 で「領域」を使用している。

注 5) 男 4(7) は写真 25 女 4 (17) と似た四隅に L 字型の壁を建てる構成だったが、 彼の作品は中央に神社が置かれており、写真 20 男 5 (15)のような「中心と 四隅」という配置の求心的形式の男性的一元性のイメージと見ることが
でき、女子の作品に見られる囲いとは異なると考えられる。

注 6)こうした触覚的なものは箱庭療法では重要視されており、箱内に砂が用 いられている理由の一つとなっている。その理由とは砂を触ることが創 造のための退行を促すことである。今回の実験でその意味の一端が明ら かになった。つまり砂遊びなどの触覚的遊びは、箱庭作成の原初的段階 で頻繁に現れることからわかるように、人間の創造的行為の根本にある 要素の一つで、それが解発されることにより、その後の創造的行為が点 火されるのである。事実、5歳児組でも初め何をしていいかわからず、 砂をいじったりするが、そのうちにリラックスしてきて、いろいろな遊 びが始まるといった例が存在した（事例女 5 (2)や事例男 5 (14)など）。

注 7) 女子の場合は、構造化された作品の全てが女性的一元性のイメージを中 心とするものであったが、そこでは家族の生活などがイメージされ、あ るいは演じられた。写真 21 女 5 (9)ではお父さんが飛行機（右上）で出張 する場面などが演じられた。

注 8）5歳児組を対象とした箱庭実験は 2011、2012 年に行っている。前者は 坂戸が行ったものが多く、後者は河内一人で行った。2011 年の実験では 単調な羅列か、余計なもののないすっきりした構造化の例が多く、中間 的なものは少なかった。一方 2012 年の事例は中間的なものが多く、混沌 でも 4 歳児組のものと違って場的空間が多数ある作例や、構造化でも混 沌的傾向の強いもの（場的な隙間が多いものなど）が多かった。写真 41 はそうした中間段階の考察のために提示した 2012 年の作例である。

注 9) 既発表論文 $\mathrm{v}$ で箱庭に現れる男女の基本的イメージが生物学的由来をも っていること、また人類始原の姿をとどめていたといわれる狩猟採集民 ブッシュマンの男女それぞれの生活空間と多くの側面で重なことを示し た。女性的一元性のイメージはブッシュマン女性の生活空間のみならず、 広く哺乳類の雌に見られる集団（群れ）内部的な行動様式のイメージと 重なる。多元性のイメージはキャンプの外に広がる男性の狩猟の空間と 重なる（様々な領域と、移動する主体、また客体としての動物たち）。ま た箱庭に明瞭に現れているように、小さな子供は一般に動物に興味をも つが、それは自らの生息環境を学習するために進化してきた心理生物学 的メカニズムによると考えられる。

注 10）世界像遊びに関しては、既発表論文 i 、p.86、既発表論文iii、p.114、 既発表論文iv 、p. 116

注 11) なお羅列段階の既存玩具をずらす程度の操作と構造化段階の空間的な 操作（「再配置、吟味」と「空間設置」）との中間的段階のものとして 項目 11 の「単純移動」で示寸次のような操作が現れる。例えば内容が移 り変わっていく変転の場合、原初的な内容の場合でも、場面の移り変わ りに従い、既にある玩具を撤去したり、移動させたりする。またもう一 段進んだ段階では、例えば不要な物を撤去したり、置いてあったディー ゼル車を移動して、そこに駅を置くといった操作が現れる。それは空間 的関係以前の物と物の関係の段階といえる。

表 1 に関しては、「単純移動」の段階にも「他をずらす」操作は現れ、 構造化の段階にも「他をずらす」、「単純移動」は現れるが、表では一 番高い段階として現れたものを○で表示している。

注 12) 女性的一元性のイメージが女性の原型的イメージであることは既発表 論文ix参照。男性的一元性のイメージは多元性のイメージがより自己主 張的な方向へ変形したものと考えられる。ヨーロッパを初め大陸の諸文 明の男子においては男性的一元性のイメージが彼らの世界内存在の様態 を表していることを既発表論文 $\mathrm{x}$ で論じたが、幼児におけるその出現の 兆しに関しては、ブラジルの子供たちの箱庭作品の考察を通して別稿で 論じる予定である。

注 13) 岡崎らが知的障害児に対しておこなった居住空間構成法の作品群を見 ると、本稿で羅列に分類した作例に類似したものが大半である印象をう ける。これは演じる遊び、そして世界像遊びが発達しなかったことによ ると考えることができよう。参考文献 4 。

注 14) 羅列の段階では、並べられた物体の視覚的効果により、さらに並べ立 てようとする欲求が惹起され、場的な空間の増加の段階では、並べられ た玩具間に空間を見いだすことで、さらにいくつもの場的隙間を見いだ していく。このように、とりあえず何かをすることでさらにやりたいこ とを発見していく、つまり結果のフィードバックにより、さらに先に進 めていくというパターンは、以降、遊びや学習その他の行動における基 本的パターンとして存続し続ける。

注 15) 岡崎らは羅列段階で現れている諸特徴に関して、「機械的で均質、そ して幾何学的な空間構成が、現代的建築や伝統的な宗教建築などの空間 と類似することも多い」と述べている。参考文献 3、p.319 


\title{
RESEARCH ON HUMAN INVENTIVENESS ORIGINS THROUGH KINDERGARTEN CHILDREN'S SANDPLAY WORKS
}

\author{
Shozo SAKATO*, Ayu KAWAUCHI** and Adriana HIGASHINO *** \\ * Prof., Dept. of Architecture, National Institute of Technology, Akashi College, Japan, Dr.Eng. \\ ** Grad. Stud., Graduate School of Humanity and Science, Ochanomizu Univ. \\ *** Assoc. Prof., Dept. of Architecture, National Institute of Technology, Akashi College, Japan, Dr.Eng.
}

This study utilizes sandplay experiments as a means to analyze the development of 4 and 5 year old kindergarten children's creative spatial organization of toys. The children were asked to arrange several toys in a box filled with sand, and they were told to play in the sand box and with the toys freely.

Fifty-one children, 25 boys and 26 girls between 4 and 5 years old, participated in the sandplay experiments. By analyzing the displacement of the toys in the box, the researchers were able to identify and classify the children's developmental steps in the creation and recognition of their spatial organization of the toys ranging from simple toy arrangements to more complex ones. "Enumeration" was the simplest example of toy arrangement, where the children enjoyed placing the toys in the box one after the other, and they did not establish any meaningful relationship between the toys. Some children placed the toys in a disorderly fashion, while others placed the toys in rows. When the toys were arranged in rows, they showed an emphasis in a certain direction. As an example, some children had all the toys facing right, other children made rows of toys parallel to the box sides. The "chaotic" classification is another example of a simple toy arrangement, where the children randomly and sometimes unstoppably stuffed toys in the box. Consequently, this resulted in a box that was completely packed with toys.

The toy arrangement classified as "structured arrangement" refers to examples where the children gave meaning and a clear spatial relationship to the toys and how the toys were displayed in the box. Two archetypical spatial images were identified in those structured arrangements. Boys had a tendency to show what is described hereafter as "spatial plurality," while girls, in contrast, presented a different tendency toward "female spatial singularity."

Spatial plurality appeared when the toys were arranged in a way that incorporated motion (cars, trains, boats) or intrusion and expanding spaces outside of the box. On the other hand, female spatial singularity was seen when the toys were arranged in an enclosed area; and, the relationship between the toys was one of inclusion, and the toys were restrained to the box. The girls placed the toys in a manner that created these internal spaces. For example, they used furniture toys and simulated the inside of a house, or they used toy figures of people and animals to suggest that they were living happily together.

These archetypical spatial images have already been identified in former sandplay experiments with older subjects. In this study with kindergarten age children the differences between boys and girls spatial images were identified in all of the structured arrangements. However, in the experiments herein, structured arrangements were fewer than the enumeration or chaotic arrangements. Some children showed the characteristics of spatial plurality or female spatial singularity, when they started placing the toys; but, at the end, they finished by filling all of the empty spaces with toys. Other children would place the toys in rows; but, in a corner of the box, they would place a table and a chair or a hospital and an ambulance, showing a start on giving meaning and spatial relationships to the toys.

These examples of arrangements between simple and structured showed the first steps towards spatial recognition. The children's intellectual capacity for recognizing and interacting with spatial organization appears in the form of this structural arrangement schema - spatial plurality or female spatial singularity. 